\title{
Ichthyofauna of the hydrographic basin of the Chasqueiro Stream (Mirim Lagoon system, southern Brazil): generating subsidies for conservation and management
}

\author{
Fabiano Corrê $a^{1,3}$, Edson Fontes de Oliveira ${ }^{2}$, Thiago Tuchtenhagen ${ }^{I}$, Juvêncio Pouey ${ }^{I}$ \& Sérgio Piedras ${ }^{I}$ \\ ${ }^{1}$ Universidade Federal de Pelotas, Departamento de Recursos Pesqueiros, Pelotas, RS, Brazil. \\ ${ }^{2}$ Universidade Tecnológica Federal do Paraná, Departamento de Engenharia Ambiental, \\ Londrina, PR, Brazil. \\ ${ }^{3}$ Corresponding author: Fabiano Corrêa, e-mail: correafecologia@yahoo.com.br
}

CORREAA. F., OLIVEIRA, E.F., TUCHTENHAGEN, T., POUEY, J., PIEDRAS, S. Ichthyofauna of the hydrographic basin of the Chasqueiro Stream (Mirim Lagoon system, southern Brazil): generating subsidies for conservation and management. Biota Neotropica. 15(4): e0006. http://dx.doi.org/10.1590/16760611-BN-2015-0006

\begin{abstract}
Studies that organize lists of species are essential and act as the starting point for future discussions on the ecology of fish in environments that are poorly studied. The present paper describes the fish assemblage of the hydrographic basin of Chasqueiro Stream, an important component of the Mirim Lagoon system. Fish were collected during one year period between August/2012 and July/2013 in six sites, comprising three biotopes: upstream, reservoir and downstream. A total of 22,853 specimens were collected, and were distributed into 83 species, 20 families, and eight orders. The two species with the largest number of individuals captured were Bryconamericus iheringii with 2,904 (12.71\%) and Cheirodon ibicuiensis with 2,868 (12.55\%). Characiformes and Siluriformes were the most representative orders in terms of richness and abundance. Bryconamericus iheringi and Cyanocharax alburnus were the species with the highest abundance upstream, while Hyphessobrycon luetkenii and Corydoras paleatus contributed more to the abundance downstream. Cheirodon ibicuhiensis and Heterocheirodon jacuhiensis were the most representative species in the reservoir. This study revealed a rich fauna of fish, which should be preserved for future generations and for the maintenance of local and regional biodiversity.
\end{abstract}

Keywords: Neotropical region, costal plain, Patos-Mirim Lagoon system.

CORRÊA. F., OLIVEIRA, E.F., TUCHTENHAGEN, T., POUEY, J., PIEDRAS, S. Ictiofauna da bacia hidrográfica do arroio Chasqueiro (sistema da Lagoa Mirim, sul do Brasil): gerando subsídios para plano de conservação e gestão. Biota Neotropica. 15(4): e0006. http://dx.doi.org/10.1590/1676-0611-BN2015-0006

Resumo: Estudos que organizam listas de espécies são essenciais como ponto de partida para futuros debates sobre a ecologia de peixes em ambientes que são pouco estudados. O presente artigo descreve a fauna de bacia hidrográfica do arroio Chasqueiro, componente importante do sistema da Lagoa Mirim. Os peixes foram coletados no período de um ano, entre os meses de agosto de 2012 e julho de 2013, em seis locais amostrais, que compreendem três biótopos, montante, reservatório e jusante. Um total de 22.853 indivíduos foi coletado, distribuídos em 83 espécies, 20 famílias e oito ordens. As duas espécies com maior abundância foram Bryconamericus iheringii com 2.904 (12,71\%) e Cheirodon ibicuiensis com 2.868 (12,55\%). Characiformes e Siluriformes foram as ordens mais representativas em termos de riqueza e abundância. Bryconamericus iheringii e Cyanocharax alburnus foram as que apresentaram as maiores abundâncias a montante, Hyphessobrycon luetkenii e Corydoras paleatus contribuíram mais na abundância a jusante, enquanto no reservatório as mais abundantes foram Cheirodon ibicuhiensis e Heterocheirodon jacuhiensis. Este estudo revelou uma rica ictiofauna na bacia hidrográfica do arroio Chasqueiro, a qual deveria ser preservada para as gerações futuras e para a manutenção da biodiversidade local e regional.

Palavras-chave: Região neotropical, planície costeira, Arroio Chasqueiro, sistema lagunar Patos-Mirim.

\section{Introduction}

Having knowledge of the fish species that colonize a hydrographic basin is the first step in producing information about the structure of the local assemblage, as well as the trophic and reproductive dynamics. The Neotropical region has the highest diversity of freshwater fish species in the world, with estimates of up to approximately 8,000 species (Schaefer 1998, Lévêque et al. 2008, Albert \& Reis 2011). López-Fernández et al. (2012) emphasize that knowledge of the fish fauna is of utmost importance, because it can reveal the relative role of adaptive processes, structural complexity, evolutionary history, and morphological and functional diversification. Indeed, studies that organize lists of species are essential and act as the starting point for future 
discussions on the ecology of fish in environments that are still poorly studied (Schifino et al. 2004, Vaske et al. 2005). Agostinho et al. (2008) stress that the diversity of fish in the continental ecosystems of Brazil is poorly known, and is greatly associated with the absence of an inventory in these environments. Carrying out studies that include lists of fish species in hydrographic basins is the initial and a fundamental step to the proper management and preservation of fish fauna (Raghavan et al. 2008, Santos et al. 2015). Information about species composition is the basis for recognizing the structure of the assemblage, as well as understanding its dynamics. The detection of these patterns allows the possibility of a more precise conservation plan for the area, defining the priorities in detail.

The fish fauna of freshwater ecosystems have suffered directly from the impacts associated with urban population growth (Pendleton et al. 2014). Other factors such as the introduction of exotic species (Vitule 2012), pollution and deforestation (Carvalho et al. 2012), busbaraquatic ecosystems (Burns et al. 2006, Barletta et al. 2010), and predatory fishing have contributed significantly to the decline in species richness. It is worth mentioning that the changes and loss of natural habitats have been directly influenced by human activities, which have led to loss of biodiversity (Teixeira et al. 2005, Schindler 2007, Barros et al. 2012). For example, Daga et al. (2012), studying the influence of human activity on the fish assemblage in a sub-basin of the San Francisco River, showed that along a longitudinal gradient there is a significant urbanization effect on the fish assemblage, primarily caused by urban organic effluents and urban activity runoff. An aspect that hinders understanding of the impacts of human activities on the fish community in a hydrographic basin is the lack of studies about local or regional species composition.

Among the countries that form the Neotropical region, Brazil has around 2,500 freshwater fish species in its hydrological systems (Reis et al. 2003, Buckup et al. 2007), which is related to the large diversity of aquatic systems present in its different biomes. In southern Brazil, transgression and regression events created the largest lagoon complex in South
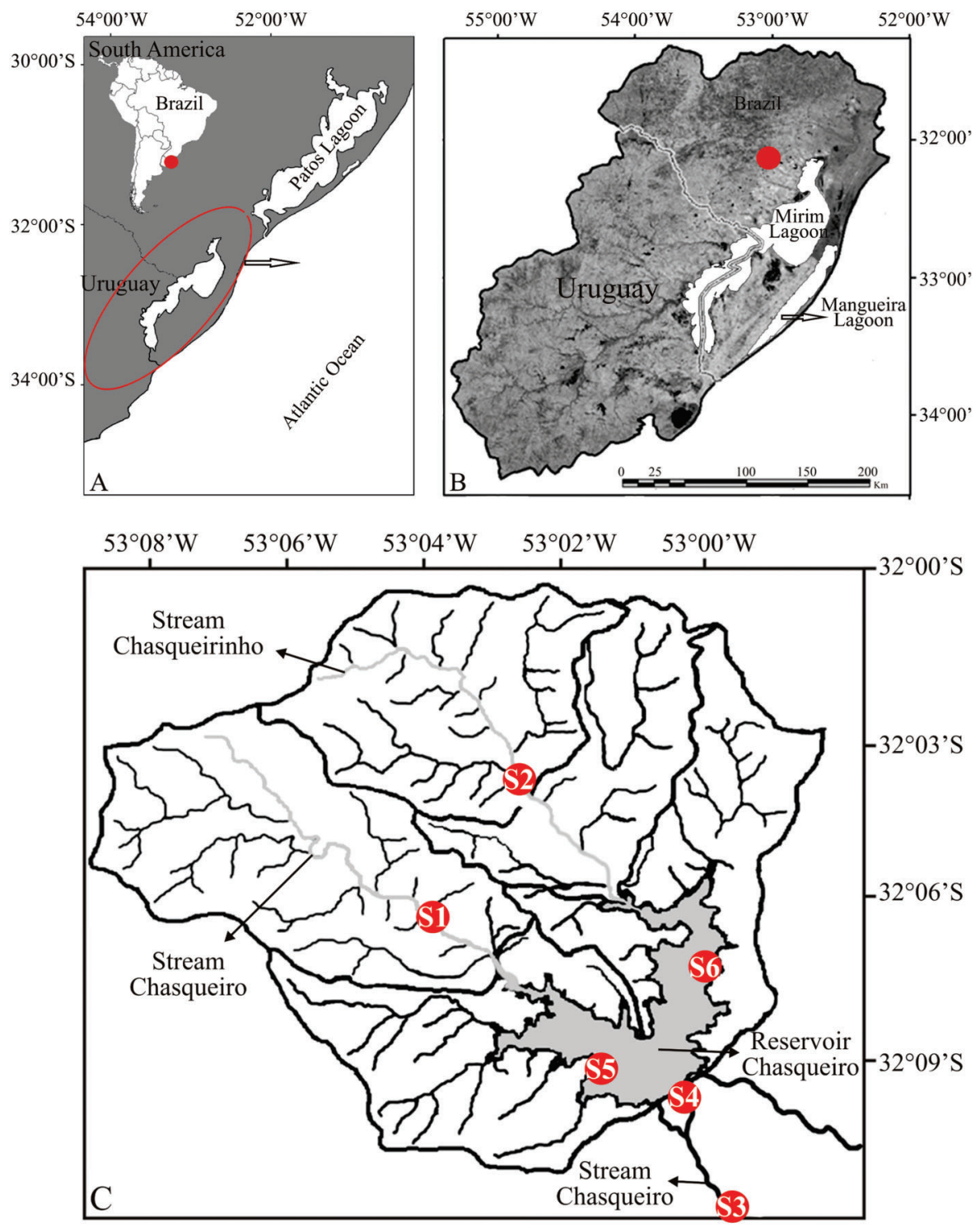

Figure 1. Study area, showing south America with the countries Brazil and Uruguay, delimitation of Mirim Lagoon system (circle red) (A), localization of hydrographic basin Chasqueiro Stream (dot red) (B) and samples sites, 1 and 2 (upstream), 3 and 4 (downstream), 5 and 6 (reservoir) (C). 
America, formed by the Patos and Mirim lagoons, which together comprise an area of about $14,000 \mathrm{~km}^{2}$ (Villwock 1987 , Kotzian \& Marques 2004). It is worth mentioning that the communication between the Patos and Mirim lagoon systems occurs through a natural channel called São Gonçalo. In 1977, a dam was constructed to prevent the entry of salt water into the region of Mirim Lagoon, the main water source used for agriculture, particularly for rice cultivation (Burns et al. 2006, Corrêa et al. 2015). The hydrographic system of Mirim Lagoon is formed by a complex composed of 22 basins, distributed between Brazil and Uruguay (Kotzian \& Marques 2004). However, there is still an absence of studies and knowledge of the fish fauna occurring in the sub-basins located in southern Brazil (Buckup \& Reis 1997, Garcia et al. 2006, Ceni \& Vieira 2013). In this context, the present study describes the fish assemblage of the hydrographic basin of Chasqueiro Stream, an integral part of the Mirim Lagoon system, with the goal of contributing to the advancement of knowledge on the composition of its ichthyofauna, as well as the production of information that can be used in action protocols aiming the system conservation.

\section{Material and methods}

The hydrographic basin of Chasqueiro Stream (BHAC) is located in the western region of the hydrographic system of Mirim Lagoon, municipality of Arroio Grande, southern Brazil (31 $\left.{ }^{\circ} 61^{\prime} \mathrm{S} / 50^{\circ} 517^{\prime} \mathrm{W}\right)$ (Figure 1). The region has a subtropical climate (according to Köppen), with an average annual rainfall ranging from 1,200 to $1,450 \mathrm{~mm}$, with monthly average temperatures of $25^{\circ} \mathrm{C}$ in the hottest months and $11^{\circ} \mathrm{C}$ during the coldest. The BHAC is formed by two principal streams (Chasqueiro and Chasqueirinho) and a reservoir. The area upstream from the reservoir is $248.42 \mathrm{~km}^{2}$, and is formed by the Chasqueiro Stream $\left(114.84 \mathrm{~km}^{2}\right)$ and the Chasqueirinho Stream $\left(133.58 \mathrm{~km}^{2}\right)$ basins. Chasqueiro Reservoir has an area of 1,800 ha, and is used primarily for rice monoculture (Sondotécnica 1986). Six sampling points were established along the BHAC: upstream - sites 1 (Chasqueiro Stream) and 2 (Chasqueirinho Stream); downstream - sites 3 and 4 (Chasqueiro Stream); Chasqueiro Reservoir - sites 5 and 6 (Figure 1; Figure 2) and a description of the sampling sites is shown in Table 1. Fish were collected monthly for one year between August/2012 and July/ 2013 (SISBIO \#n.34389-1), totaling 72 samples. Because of the diversity of habitats that were investigated, it was not possible to maintain a standardized effort for all points and became necessary to employ different collection apparatuses, assuming that the use of the set of fishing gear increased the sampling efficiency. The following apparatuses were used: a) gill net: $75 \mathrm{~m}$ long with 10 meshes; 20, 30, 40 and $50 \mathrm{~mm}$ (knot to knot) submerged for a period of $24 \mathrm{~h}$ (checked after $12 \mathrm{~h}$ ); used in reservoir depths between 1.0 and $2.5 \mathrm{~m}$ in order to capture larger individuals ( $>200 \mathrm{~mm}$ ); b) beam trawl: $5 \mathrm{~m}$ long, $2.25 \mathrm{high}$, with $5 \mathrm{~mm}$ mesh (knot to knot) employed in the coastal zones of the reservoir and downstream, with five trawls at each site per collection; c) two dip nets: $5 \mathrm{~mm}$ mesh opening, $35 \mathrm{~cm}$ wide and $50 \mathrm{~cm}$ long, used upstream and downstream in areas with and without vegetation, and used for 30 minutes at sites with depths
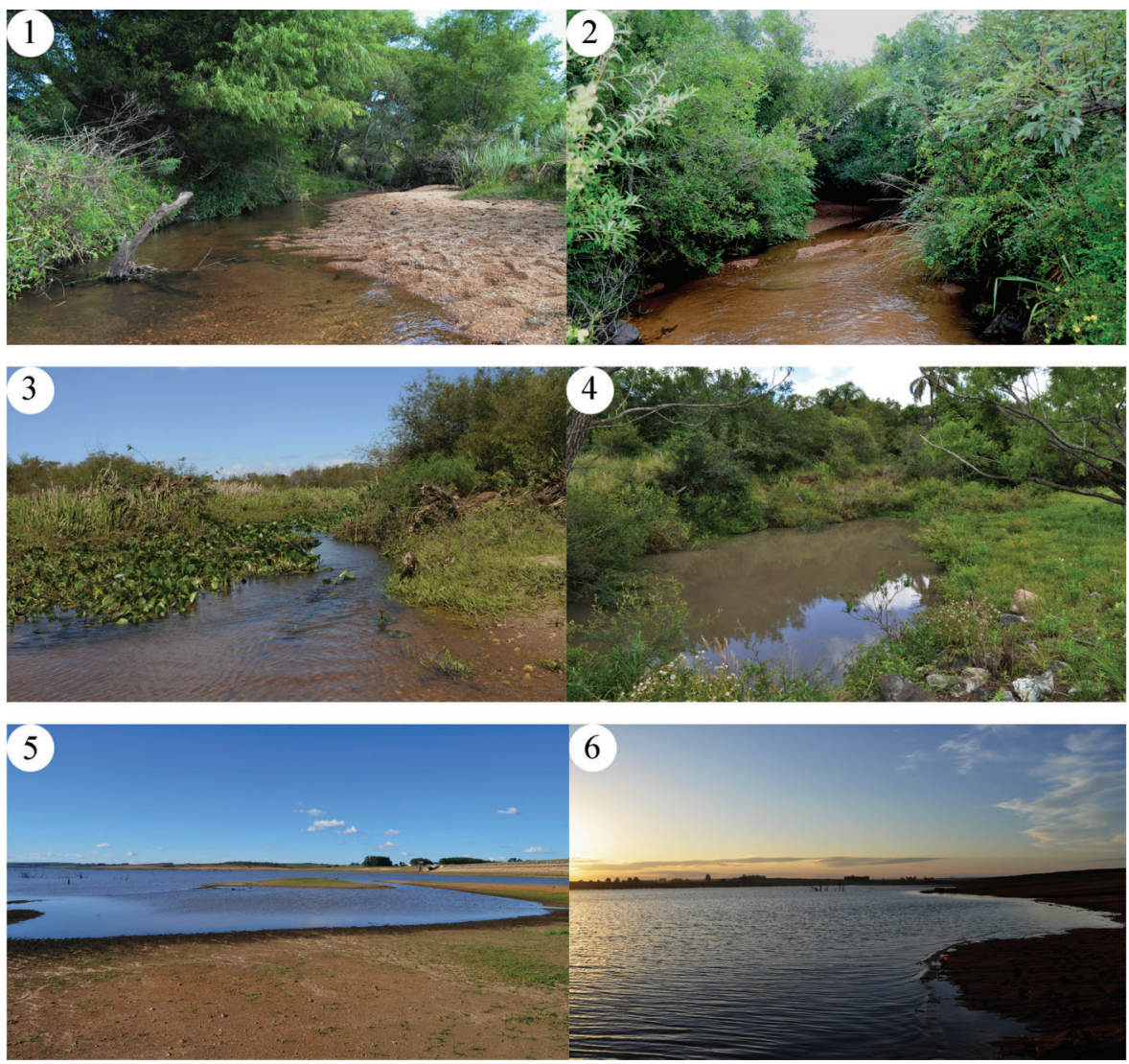

Figure 2. Photograph of the sampling sites 1 and 2 (upstream), 3 and 4 (downstream), 5 and 6 (reservoir) (C), hydrographic basin Chasqueiro Stream, Mirim Lagoon system, southern Brazil. 
Fabiano C. et al.

Table 1. Characterization of sampling sites, upstream, downstream and reservoir, presenting the biotopes, general characteristics, substrate and geographic coordinates, the sites located in the hydrographic basin of Chasqueiro Stream, Mirim Lagoon system, southern Brazil.

\begin{tabular}{|c|c|c|c|c|}
\hline $\begin{array}{l}\text { Sample } \\
\text { sites }\end{array}$ & Biotopes & General characteristics & Substrate & $\begin{array}{l}\text { Geographic } \\
\text { coordinates }\end{array}$ \\
\hline S1 & Upstream & $\begin{array}{l}\text { Margins formed by pastures. In some } \\
\text { stretches, herbaceous individuals, shrub, } \\
\text { and tree species are found; for example, } \\
\text { Eryngium spp., Baccharis spp., and Salixum } \\
\text { boldtiana, respectively. It features an } \\
\text { average width of } 7.9 \mathrm{~m} \text { and an average } \\
\text { depth of } 29.1 \mathrm{~cm} \text {. Features locations with } \\
\text { little riffle and pool. }\end{array}$ & $\begin{array}{l}\text { The substrate consists of } 97.9 \% \text { sand, } 1.6 \% \\
\text { clay, and } 12.5 \% \text { silt. Presence of boulders } \\
\text { derived from anthropogenic activities. }\end{array}$ & $\begin{array}{l}32^{\circ} 07^{\prime} \\
43.97^{\prime \prime} \mathrm{S} 53^{\circ} \\
03^{\prime} 8.03^{\prime \prime} \mathrm{W}\end{array}$ \\
\hline S2 & & $\begin{array}{l}\text { Both margins contain arboreal vegetation. } \\
\text { Presence of groups of rooted herbaceous } \\
\text { species in stream bed. Shading occurs } \\
\text { around } 80 \% \text { of the water. Left margin with } \\
\text { siltation in the bed of course. Has an } \\
\text { average width of } 7.6 \mathrm{~m} \text { and average depth of } \\
43.8 \mathrm{~cm} \text {. Present locations with little riffle } \\
\text { and pool. }\end{array}$ & $\begin{array}{l}\text { The substrate consists of } 99.4 \% \text { sand, } 0.4 \% \\
\text { clay, and } 0.2 \% \text { silt. Occurrence of boulders } \\
\text { derived from anthropogenic activities. }\end{array}$ & $\begin{array}{l}32^{\circ} 06^{\prime} \\
05.89^{\prime \prime} \mathrm{S} 53^{\circ} \\
03^{\prime} 0.94^{\prime \prime} \mathrm{W}\end{array}$ \\
\hline S3 & Downstream & $\begin{array}{l}\text { Presence of free and floating aquatic } \\
\text { macrophytes such as Eichhornia crassipes } \\
\text { and rooted Polygonum punctatum. Groups } \\
\text { of shrubs and tree species on both sides of } \\
\text { individuals such as Calliandra brevipes. } \\
\text { Average width of } 6.2 \mathrm{~m} \text { and average depth } \\
\text { of } 31.9 \mathrm{~cm} \text {. Presents with a flow site and } \\
\text { with a predominance of local shallows. }\end{array}$ & $\begin{array}{l}\text { Substrate consisting of } 90.67 \% \text { sand, } \\
10.08 \% \text { clay, and } 23.1 \% \text { silt. }\end{array}$ & $\begin{array}{l}32^{\circ} 12^{\prime} \\
11.08^{\prime \prime} \mathrm{S} 52^{\circ} \\
58^{\prime} 9.70^{\prime \prime} \mathrm{W}\end{array}$ \\
\hline S4 & & $\begin{array}{l}\text { On both sides graminóide is the } \\
\text { predominant vegetation. Posterior part of } \\
\text { the left bank reveals an arboreal stratum. } \\
\text { Presence of floating aquatic macrophytes. It } \\
\text { features shadowing of the water depth } \\
\text { around } 50 \% \text {. Has an average width of } 5.0 \mathrm{~m} \\
\text { and average depth of } 66.7 \mathrm{~cm} \text {. Environment } \\
\text { essentially shallows. }\end{array}$ & $\begin{array}{l}\text { Predominantly sand with } 90.5 \% \text {, followed } \\
\text { by silt and clay with } 5.5 \% \text { and } 3.9 \% \text {. }\end{array}$ & $\begin{array}{l}32^{\circ} 09^{\prime} \\
55.73^{\prime \prime} \mathrm{S} 53^{\circ} \\
00^{\prime} 9.46^{\prime \prime} \mathrm{W}\end{array}$ \\
\hline S5 & Reservoir & $\begin{array}{l}\text { Margins are predominantly anthropogenic } \\
\text { fields of grasses used for grazing. }\end{array}$ & $\begin{array}{l}\text { The site has a substrate with a } \\
\text { predominance of } 73.60 \% \text { sand, followed } \\
\text { by clay and silt with } 14.0 \% \text { and } 12.4 \% \text {. } \\
\text { Local occurrence of boulders. }\end{array}$ & $\begin{array}{c}32^{\circ} 10^{\prime} \\
05.09^{\prime \prime} \mathrm{S} 53^{\circ} \\
01^{\prime} 6.53^{\prime \prime} \mathrm{W}\end{array}$ \\
\hline S6 & & $\begin{array}{l}\text { It features anthropogenic fields consisting } \\
\text { of grasses used for grazing on the shores. }\end{array}$ & $\begin{array}{l}\text { A predominance of sand substrate with } \\
73.5 \% \text {, followed by clay and silt with } 14.0 \% \\
\text { and } 12.2 \% \text {. Locations with muddy bottoms } \\
\text { are present. }\end{array}$ & $\begin{array}{l}32^{\circ} 08^{\prime} \\
59.69^{\prime \prime} \mathrm{S} 53^{\circ} \\
00^{\prime} 1.16^{\prime \prime} \mathrm{W}\end{array}$ \\
\hline
\end{tabular}

of $10 \mathrm{~cm}$ to one meter and d) one sieve with $5 \mathrm{~mm}$ mesh, $80 \mathrm{~cm}$ wide and $160 \mathrm{~cm}$ long, employed upstream and downstream, and used for 15 minutes per month at each site.

The collected fish were stored in plastic bags, labeled, and fixed in $10 \%$ formalin, and were then taken to the laboratory where they were transferred to $70 \%$ alcohol. Specimens were identified with the help of specialized literature (Reis \& Malabarba 1988, Buckup \& Reis 1997, Rodriguez \& Reis 2008, Caravalho \& Reis 2009, Bertaco \& Lucena 2010, Carvalho et al. 2012, Lucena et al. 2013, Malabarba et al. 2013), and specialists were consulted when needed for species confirmation. The list of species was formulated according to Wiley \& Johnson (2010) and Malabarba et al. (2013). The specimen testimonies were deposited in the ichthyological collection of the Federal
University of Rio Grande (FURG). The number of species was estimated for each sampling site, and the Shannon-Wiener diversity index ( $\left.\mathrm{H}^{\prime}\right)$ and Pielou's evenness index were also used for calculations with PAST 3.0 statistical software (PAlaeontological STatistics, Hammer et al. 2014).

\section{Results and Discussion}

A total of 22,853 individuals were collected. They were represented by 83 species, 20 families, and eight orders (Table 2). The two species with the greatest number of individuals captured were Bryconamericus iheringii $(2,904 ; 12.71 \%)$ and Cheirodon ibicuiensis $(2,868 ; 12.55 \%)$. When the data of the orders were compared among different biotopes (upstream, downstream, and 


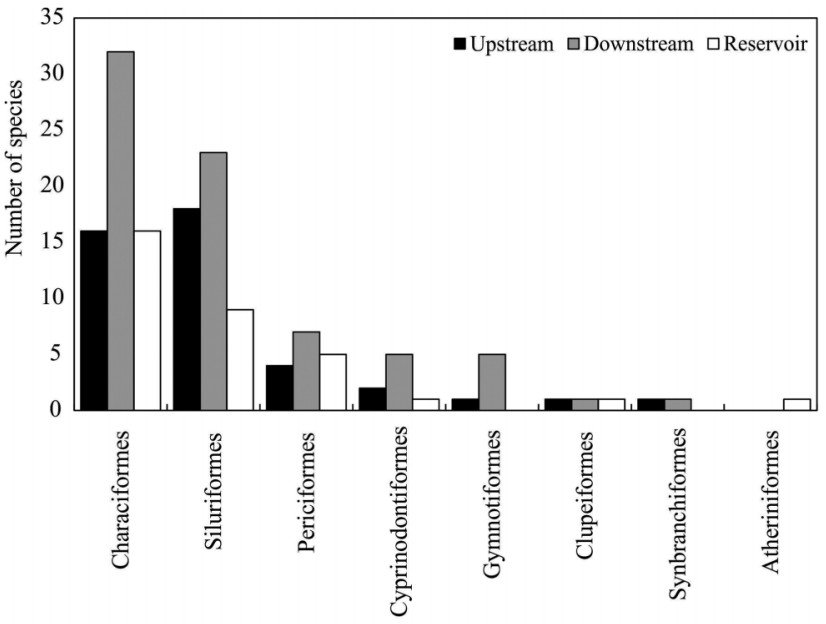

Taxonomic orders

Figure 3. Number of fish species by taxonomic order, for the three biotopes (upstream, downstream and reservoir) of hydrographic basin Chasqueiro Stream, Mirim Lagoon system, southern Brazil.

reservoir), Characiformes and Siluriformes were the most representative in terms of abundance and richness (Table 2; Figure 3). Artioli et al. (2009), studying dominance patterns of an aquatic ecosystem in southern Brazil, also recorded high abundance of Characiformes species (e.g. Bryconamericus iheringii). Similarly, Becker et al. (2013) studied the fishes of the Taquari-Antas River basin and Garcia et al. (2006) compared the dominance patterns of the fish fauna of Taim wetlands. The predominance of species belonging to Characiformes and Siluriformes corroborates studies conducted in Neotropical aquatic ecosystems (Lowe-McConnell 1999, Becker et al. 2013, Viana et al. 2013). The high diversity, as well as the abundance of Characiformes and Siluriformes in the Neotropical region, is related to several factors, e.g. the ecological and behavioral patterns of the species (Carvalho et al. 2012), diversity of ecosystems (Oliveira et al. 2012), as well as evolutionary and geological processes (Lévêque et al. 2008). Teixeira et al. (2005) emphasize that the differences in physiography over a longitudinal gradient corresponded to the changes in the diversity and abundance of the fish assemblage, where species of Characiformes and Siluriformes have wide spatial distribution.

The rarest species in the system were Trachelyopterus lucenai and Gymnotus pantherinus $(0.004 \%)$, which corroborate data reported by Artioli et al. (2009) in Mangueira Lagoon, Rio Grande do Sul state. Trachelyopterus lucenai is not considered a native species of the region, and might have come to the hydrographic basin through irrigation channels (rice fields) (Bertoletti et al. 1992, Becker et al. 2013).

Eleven species common to every collection site were identified among the upstream, downstream, and reservoir biotopes: six species of Characiformes (Astyanax eigenmanniorum, Bryconamericus iheringii, Cheirodon ibicuhiensis, Cheirodon interruptus, Cyanocharax alburnus and Hyphessobrycon luetkenii), three of Siluriformes (Corydoras paleatus, Pimellodela australis and Homodiaetus anisitsi), and two of Perciformes (Gymnogeophagus gymnogenys and Crenicichla lepidota). These species are illustrated in Figure 4.

The number of species collected represents a total of $51.87 \%$ of the 160 total species recorded for the Patos-Mirim Lagoon system (Becker et al. 2013). Studies to expand lists of fish species in the
Mirim Lagoon system were conducted in the Taim Ecological Reserve (Buckup \& Malabarba 1983, Grosser et al. 1994, Garcia et al. 2006), where 51 to 62 fish species were recorded. Based on analysis of the different sampling sites, the stretch that showed a larger number of individuals consisted of sites 3 (downstream) $(5,665 ; 24.79 \%)$ and 5 (reservoir) $(5,600 ; 25.5 \%)$. Note that downstream site 3 presents a large predominance of aquatic macrophytes that provide refuge from predators, which are important for feeding and reproduction (Lowe-McConnell 1999). However, at site 5, the high abundance may be associated with the high reproduction rate of the forage species (e.g. Cheirodon ibicuiensis and Astyanax aff. fasciatus). Agostinho et al. (1999) describe how the high abundance of forage species is associated with a high reproduction rate, as well as how feeding flexibility favors the colonization of these reservoir species.

The dominant species at site 3 was Hyphessobrycon luetkenii $(1,454 ; 25.66 \%)$, while at site 5 , Cheirodon ibicuiensis was the most representative species $(1,414 ; 25.25 \%)$. In terms of number of species, sites 3 and 4 (downstream) showed higher values of species richness $(67 ; 80.72 \%)$ and $(53 ; 63.85 \%)$, respectively. However, site 6 was less diverse $(28 ; 33.73 \%$ ) (Table 2). Bryconamericus iheringii and Cyanocharax alburnus were the species with the highest abundance upstream. Hyphessobrycon luetkenii and Corydoras paleatus contributed more to the abundance downstream. The most representative species in the reservoir were Cheirodon ibicuhiensis and Heterocheirodon jacuhiensis.

Regarding ecological indices, the upstream Shannon diversity index values were 2.57 and 2.22 at sites 1 and 2, respectively. However, the downstream Shannon diversity index values at sites 3 and 4 were greater ( 3.00 and 2.83, respectively), while the reservoir was the least diverse biotope (2.04 and 2.09) (Table 2). The same pattern can be observed in relation to the evenness index of Pielou, as the downstream sites demonstrated the highest values $(0.75$ and 0.72$)$, while the reservoir presented the lowest equitability values $(0.30$ to 0.63$)$ (Table 2$)$. At the six BHAC sampling sites, two species expanded their spatial distribution: Acestrorhynchus pantaneiro, an invasive species in the Patos-Mirim Lagoon system (Einhardt et al. 2014) and Cyphocharax spilotus, which was recorded in the northern part of this system and in the BHAC (Corrêa et al. 2014). The richness found in the BHAC may be associated with broad environmental heterogeneity, since the basin is formed by a large variety of ecosystems (rivers, streams, wetlands and reservoir). Landscapes with different lotic, lentic and semilentic aquatic systems tend to present larger functional habitats and greater microhabitat diversity for fishes, increasing the availability of feeding resources, breeding sites and refuges against predation (Matthews 1998). BHAC also showed high species diversity compared to similar studies in aquatic systems. For example, in the coastal streams of austral Brazil, Bastos et al. (2013) recorded a total of 41 species, while Artioli et al. (2009) documented the occurrence of 52 species in Mangueira Lagoon, located in the same coastal plain, with the largest values comparable to those found in other aquatic environments in southern Brazil (Lucena et al. 1994, Tagliani 1994, Malabarba et al. 2009, Carvalho et al. 2012). Lower numbers of species in the studies described above can be associated with the type of sampler, as well as lower environmental heterogeneity; however, the outstanding abundance of Characiformes and Siluriformes are documented for every location (Artioli et al. 2009, Carvalho et al. 2012, Bastos et al. 2013, Silva et al. 2014). 
Fabiano C. et al.

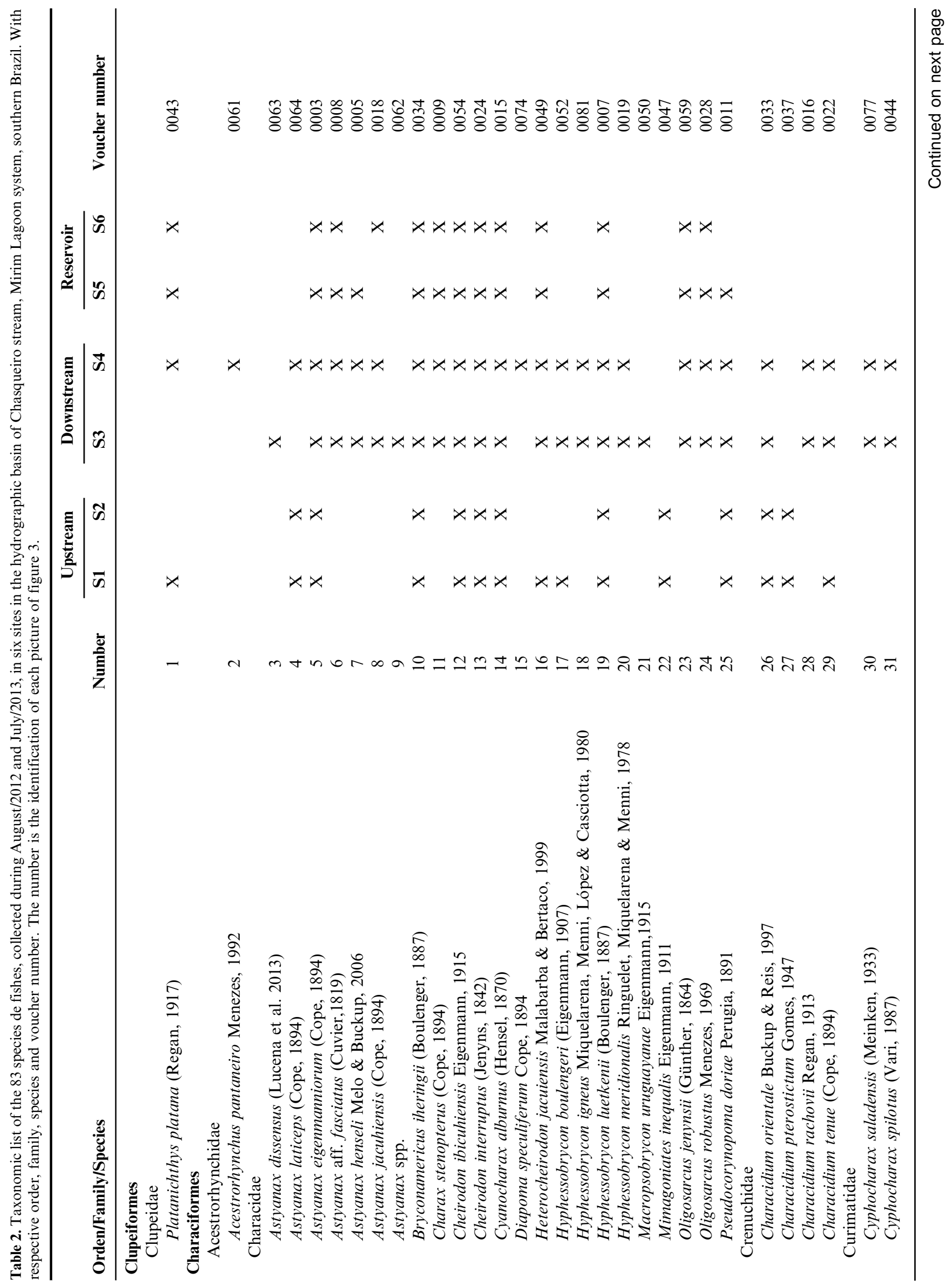




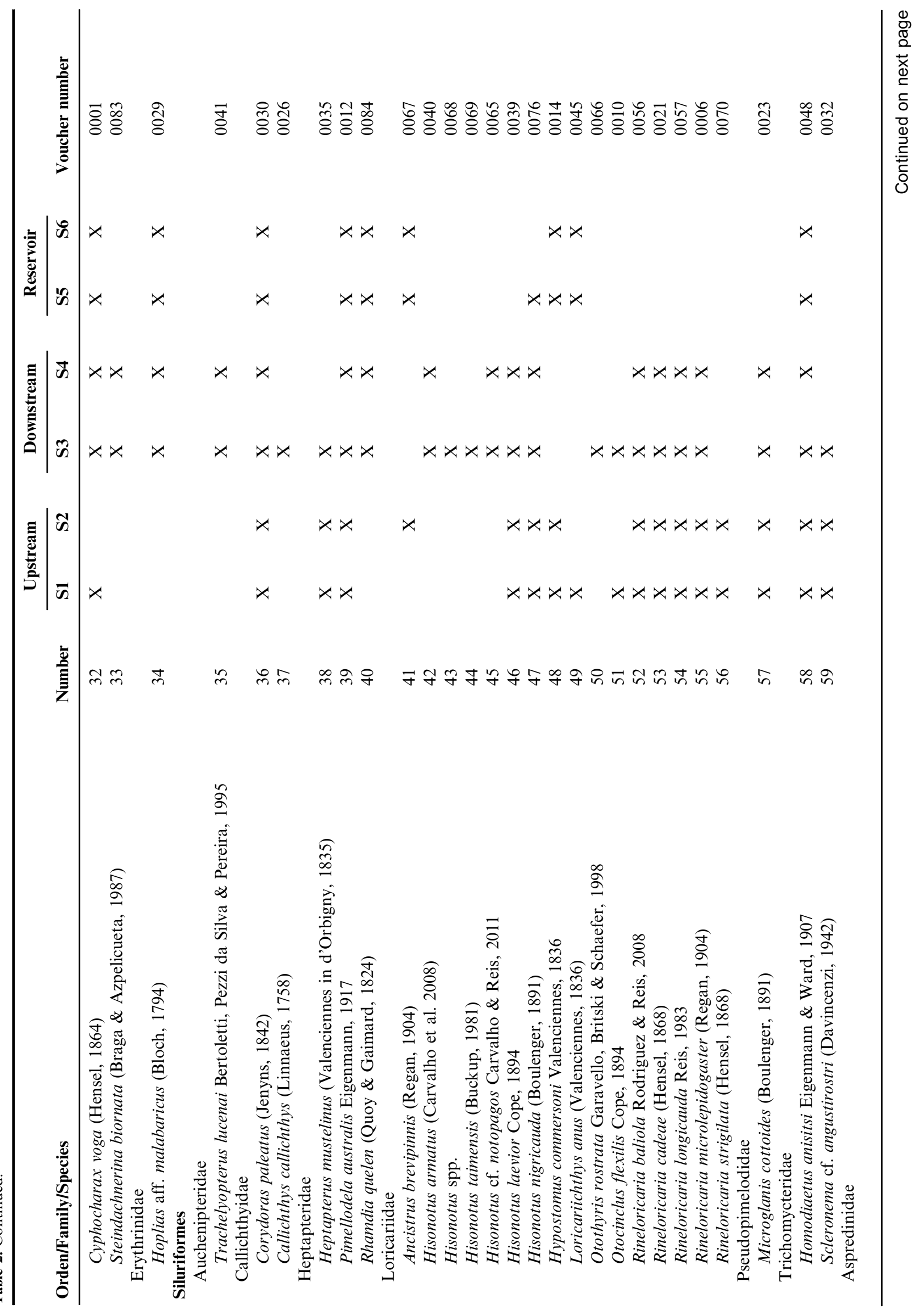


Fabiano C. et al.

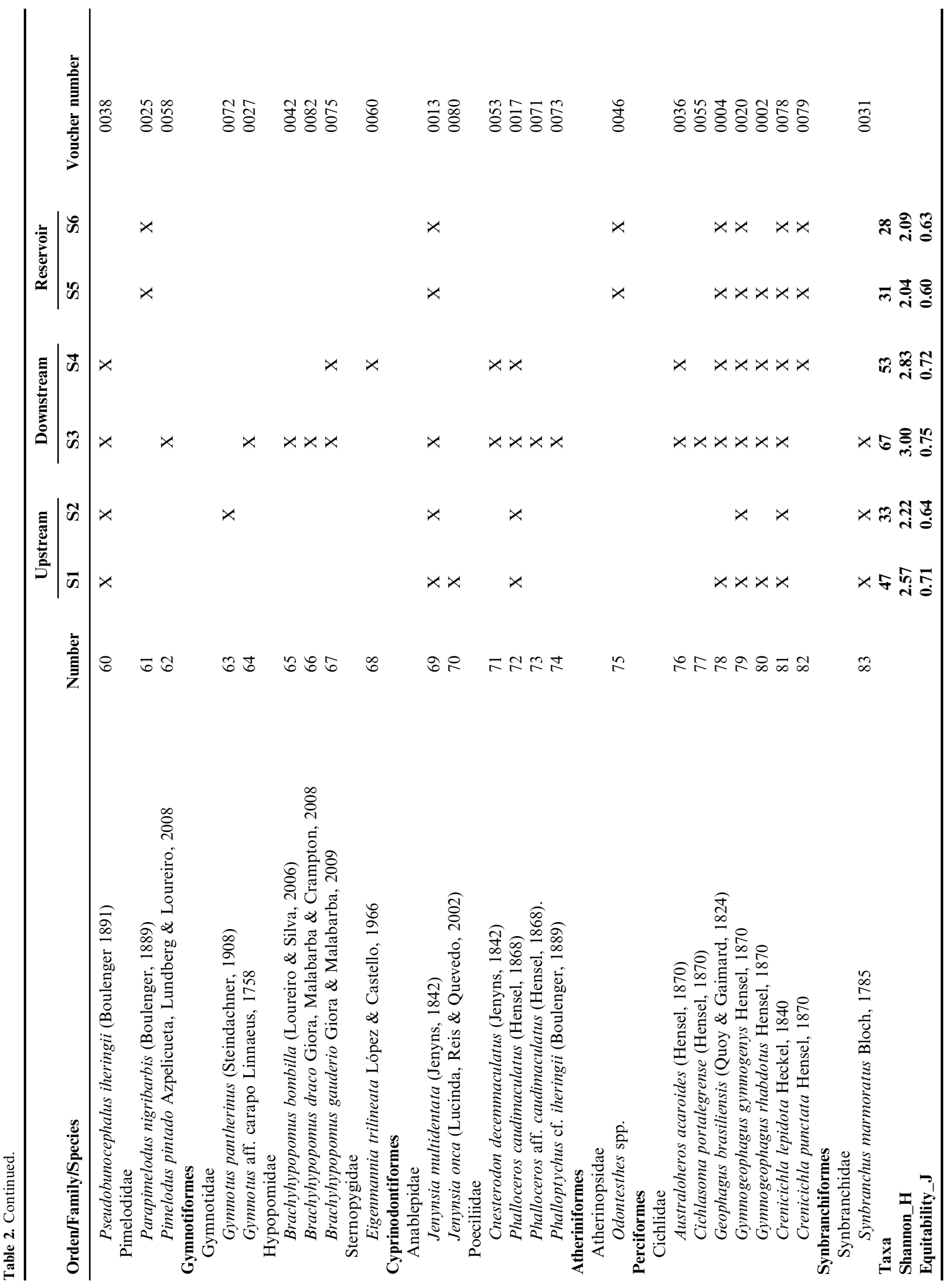



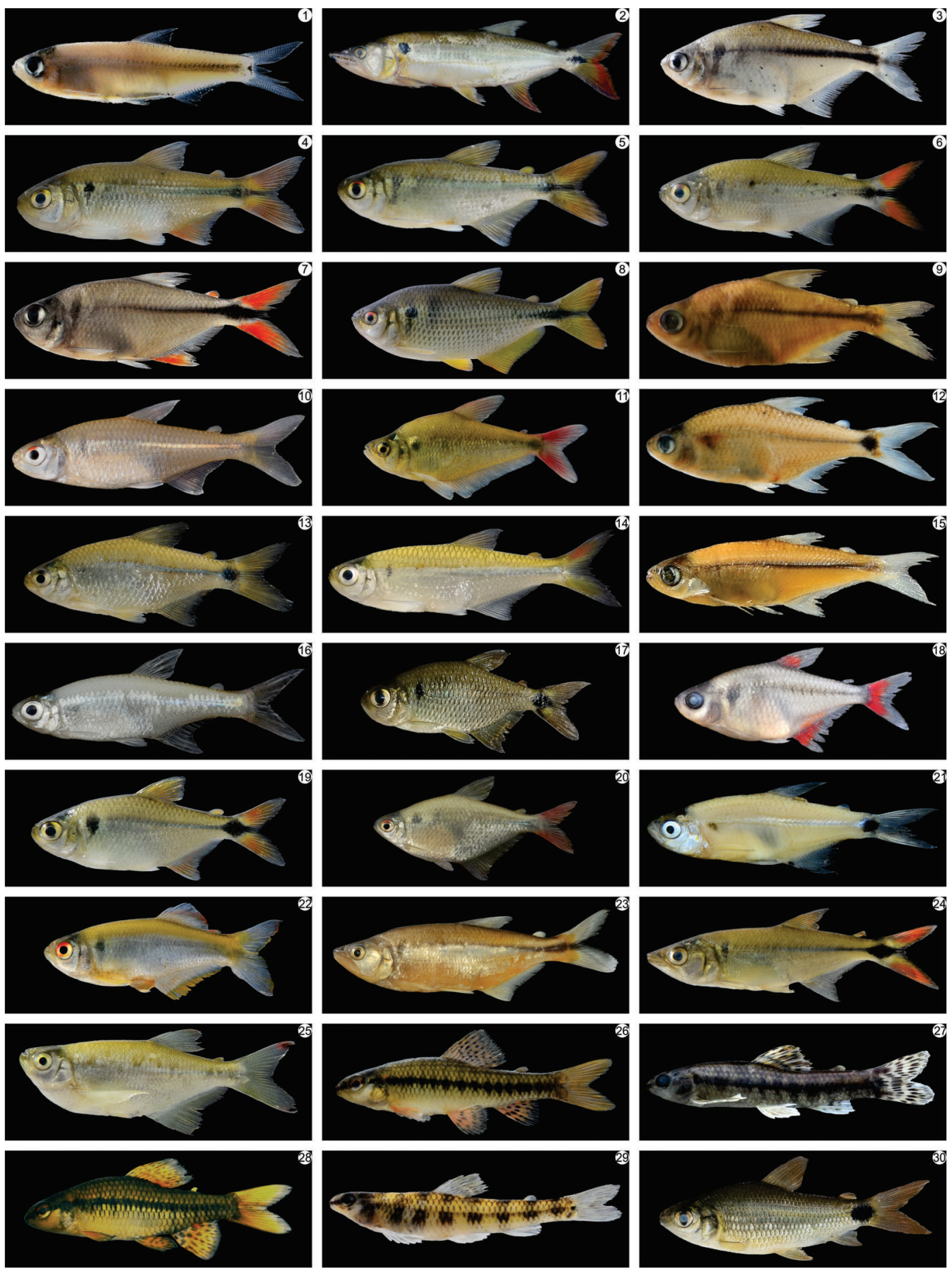

Figure 4. Picture of the 83 species of fishes collected in the hydrographic basin Chasqueiro Stream, Mirim Lagoon system, southern Brazil.

The downstream biotope presented the greatest richness, which may be related to increased diversity of habitats and micro habitats observed in this biotope, which corroborates the river continuum theory (Vannote et al. 1980), where changes along the longitudinal gradient (upstream to downstream) tend to increase the biological diversity. This is related to higher solar incidence and temperature variations, which increase structural complexity, e.g. the presence of macrophytes with this higher primary productivity. Another aspect that may influence the increase in fish diversity in a hydrographic basin is the presence of environmental barriers. Winemiller et al. (2008) explain that environmental barriers limit dispersion, which tends to influence diversity along a longitudinal gradient. Therefore, this study provides important data about ecosystems that compose the hydrographic basin of Chasqueiro Stream. Indeed, the richer biotopes were upstream and downstream, where there was better ecological and functional structure. Furthermore, there was a strong predominance of Characiformes and Siluriformes, reflecting the environmental heterogeneity of these environments. Downstream environments were 

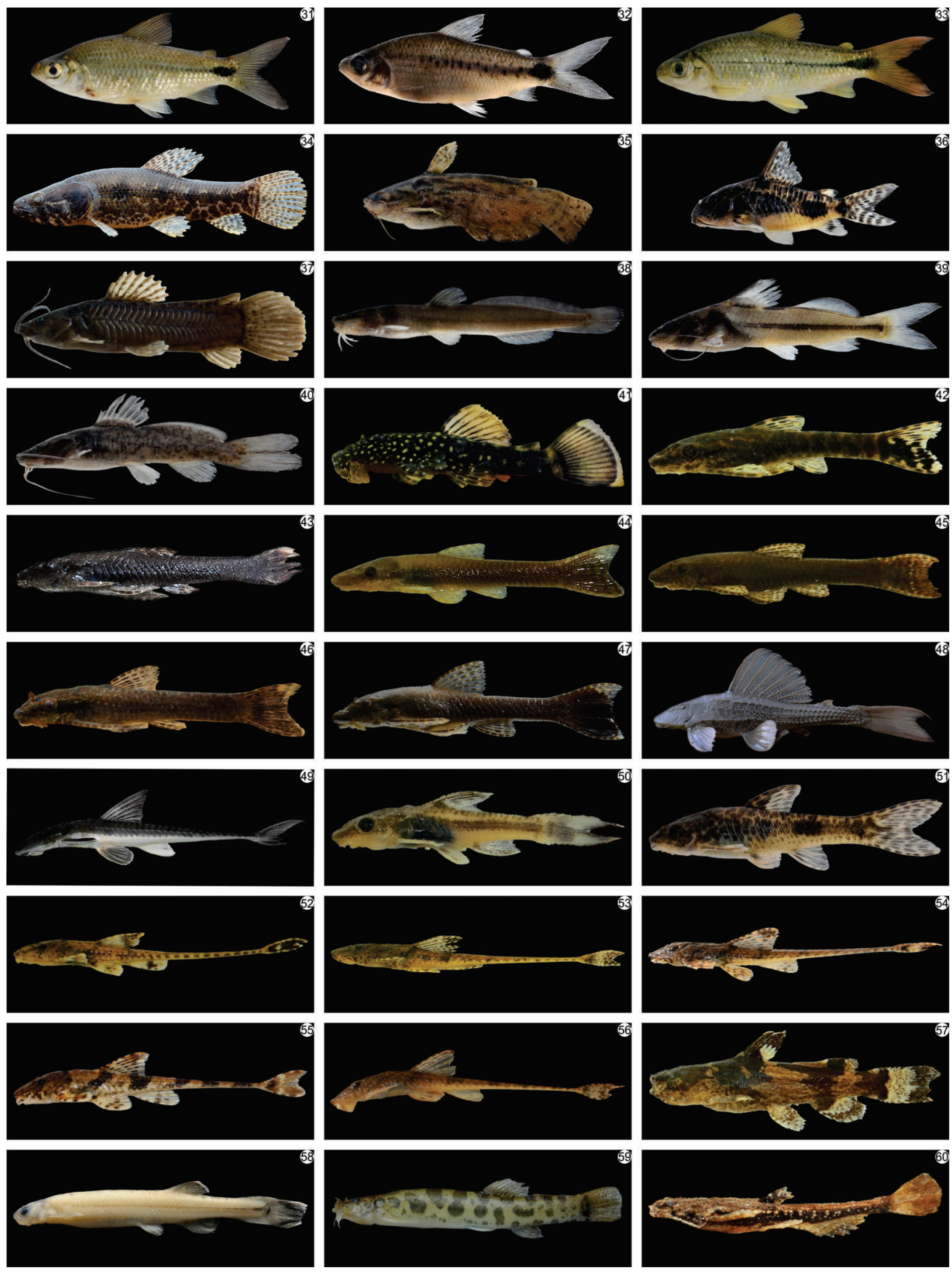

Figure 4. Continued.

more susceptible to environmental degradation caused mainly by rice cultivation.

However, the reservoir has the lowest diversity, reflecting a more homogeneous environment and the presence of invasive species (e.g. Odonthestes spp.) (Figure 4). The information mentioned above can be used for management plans and regional conservation, adopting mitigation measures for the preservation of this important ecosystem in southern Brazil. Further studies about the spatial and temporal distribution of species can help answer important questions about the dynamics of the assemblage organization, as well as provide additional assistance for formulating conservation programs for the ichthyofauna basin and greater control over environmental impacts, such as those resulting from irrigation and rice cultivation.

\section{Acknowledgments}

To Anna Carolina, Aline Luçardo, Cristiano Costenaro, Marcos Einhardt, Mariana Xavier and Roger Aguilar by assistance 

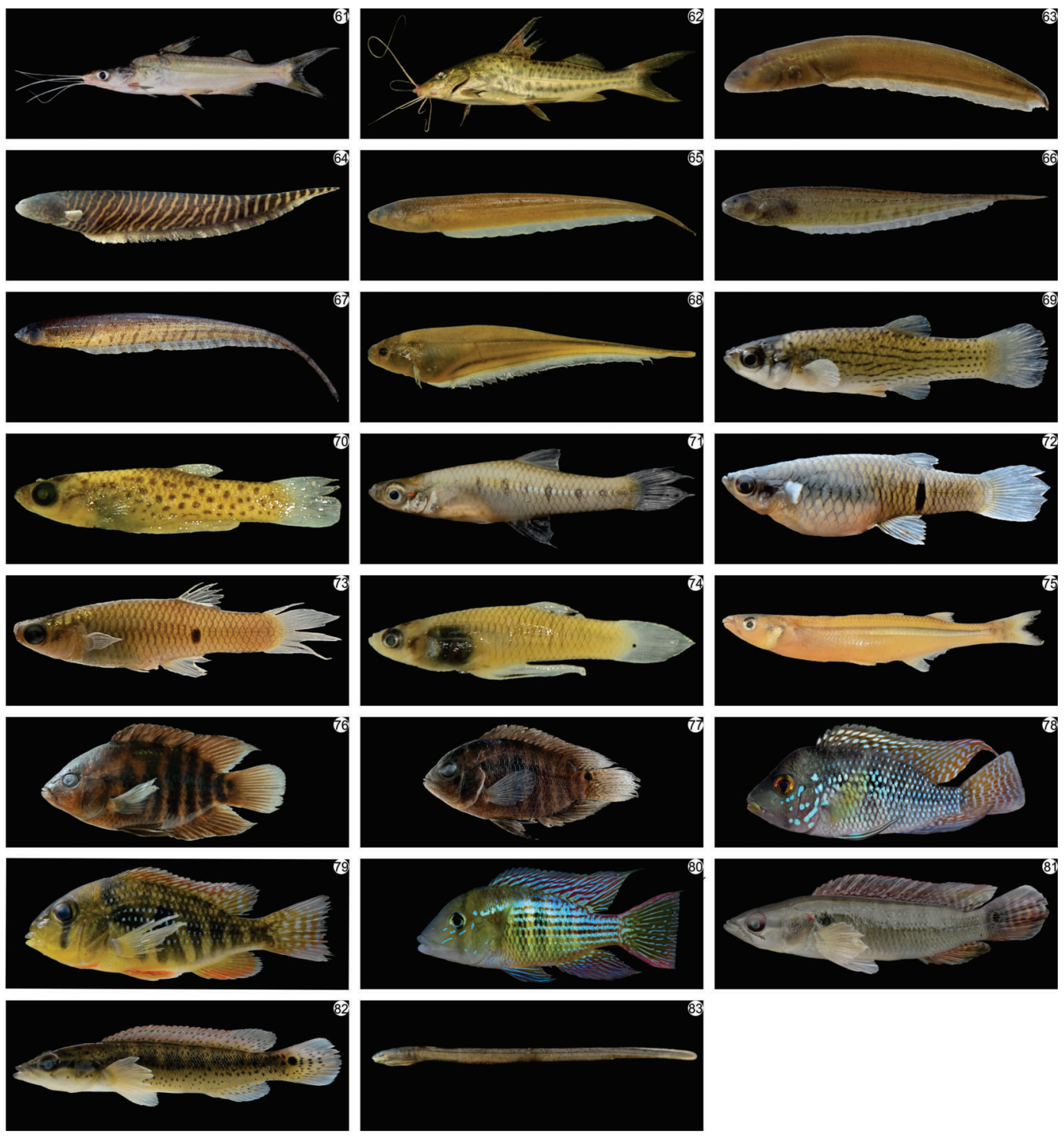

Figure 4. Continued.

in the fieldwork and laboratory, and two anonymous referees by their valuable suggestions. We are grateful to SISBIO license for the field collection, Mirim Lagoon Agency (ALG) and Coordenacão de Aperfeiçoamento de Pessoal de Nível Superior (CAPES) in terms of field study and financial support.

\section{References}

Albert, J. \& Reis, R.E. 2011. Historical Biogeography of Neotropical Freshwater Fishes. 1. ed. Berkeley: University of California Press, 388p., http://dx.doi.org/10.1525/california/9780520268685.001.0001.

Agostinho, A.A., Miranda, L.E., Bini, L.M., Gomes, L.C., Thomaz, S.M. \& Suzuki, H I. 1999. Patterns of colonization in neotropical reservoirs, and prognoses on aging. In Theoretical reservoir ecology and its applications (J. G. Tundisi \& Straskraba, M. eds.). International Institute of Ecology, São Carlos, p. 227-265.

Agostinho, A.A., Pelicice, F.M. \& Gomes, L.C. 2008. Dams and the fish fauna of the Neotropical region: impacts and management related to diversity and fisheries. Braz J Biol 68: 1119-1132, http://dx.doi.org/ 10.1590/S1519-69842008000500019.
Artioli, L.G.S., Vieira, J.P., Garcia, A.M. \& Bemvenuti, M.A. 2009. Distribuição, dominância e estrutura de tamanhos da assembleia de peixes da lagoa Mangueira, sul do Brasil. Iheringia 99: 409-418, http://dx.doi.org/10.1590/S0073-47212009000400011.

Barletta, M., Jaureguizar, A.J., Baigun, C., Fontoura, N.F., Agostinho, A.A., Almeida-Val, V.M.F., Val, A.L., Torres, R.A., Jimenes-Segura, L.F., Giarrizzo, T., Fabré, N.N., Batista, V.S., Lasso, C., Taphorn, D.C., Costa, M.F., Chaves, P.T., Vieira, J.P. \& Corrêa, M.F.M. 2010. Fish and aquatic habitat conservation in South America: a continental overview with emphasis on neotropical systems. J Fish Biol 76: 2118-2176, http://dx.doi.org/10.1111/j.1095-8649.2010.02684.x.

Barros, L.C., Santos, U., Zanuncio, J.C. \& Dergam, J.A. 2012. Plagioscion squamosissimus (Sciaenidae) and Parachromis managuensis (Cichlidae): A threat to native fishes of the Doce River in Minas Gerais, Brazil. Plos ONE 7: e39138, http://dx.doi.org/10.1371/journal.pone.0039138.

Bastos, R.F., Condini, M.V. \& Garcia, A.M. 2013. Fishs pecies list of coastal streams in southern Brazil: withn otes on austral distribution limits of marine and freshwater endangered species. Panam J Aquat Sci 8: 347-351.

Becker, F.G., Fries, L.C.C., Ferrer, J.S., Bertaco, V.A., Luz-Agostinho, K.D.G., Silva, J.F.P., Cardoso, A.R., Lucena, Z.M.S. \& Lucena, C.A.S. 
2013. Fishes of the Taquari-Antas river basin (Patos Lagoonbasin), southern Brazil. Braz J Biol 73: 79-90, http://dx.doi.org/10.1590/S151969842013000100010.

Bertaco, V.A. \& Lucena, C.A.S. 2010. Redescription of the Astyanax obscurus (Hensel, 1870) and A. laticeps (Cope, 1894) (Teleostei: Characidae): two valid freshwater species originally described from rivers of Southern Brazil. Neotrop Ichthyol 8: 7-20.

Bertoletti, J.J., Pezzi da Silva, J.F. \& Pereira, E.H.L. 1995. A new species of the catfish genus Trachelyopterus (Siluriformes, Auchenipteridae) from southern Brazil. Rev Fr Aquariol 22(3-4): 71-74.

Buckup, P.A. \& Malabarba, L.M. 1983. A list of the fishes of theTaim Ecological Station, Rio Grande do Sul, Brazil. Iheringia 63: 103-113.

Buckup, P.A. \& Reis, R.E. 1997. The characidiin genus Characidium (Teleostei: Characiformes) in southern Brazil, with the description of three new species. Copeia 3: 531-548, http://dx.doi.org/10.2307/1447557.

Buckup, P.A., Menezes, N.A. \& Ghazzi, M.S. 2007. Catálogo das espécies de peixes de água doce do Brasil. Rio de Janeiro: Museu Nacional. 195p.

Burns, M.D.M., Garcia, A.M., Vieira, J.P., Bemvenuti, M.A., Marques, D.M.L.M. \& Condini, M.V. 2006. Evidence of habitat fragmentation affecting fish movement between the Patos and Mirim coastal lagoons in southern Brazil. Neotrop Ichthyol 4: 69-72, http://dx.doi.org/ 10.1590/S1679-62252006000100006.

Carvalho, T.P. and Reis, R.E. 2009. Four new species of Hisonotus (Siluriformes: Loricariidae) from the upper rio Uruguay, southeastern South America, with a review of the genus in the rio Uruguay basin. Zootaxa 2113: 1-40.

Carvalho, F.R., Malabarba, L.R., Lenz, A.J., Fukakusa, C., Guimaraes, T.R., Sanabria, J.A. \& Morais, A. 2012. Ictiofauna da Estação Experimental Agronômica da Universidade Federal do Rio Grande do Sul, sul do Brasil: composição e diversidade. Rev Bras de Bioc 10: 26-47.

Ceni, G. \& Vieira, J.P. 2013. Looking through a dirty glass: how different canthe characterization of a fish fauna be when distinct nets are used for sampling? Zool 30(5): 499-505, http://dx.doi.org/ 10.1590/s1984-46702013000500005.

Corrêa, F., Tuchtenhagen, T., Oliveira, E.F., Pouey, J. \& Piedras, S. 2014. Distribution extension of Cyphocharax spilotus (Vari, 1987) (Characiformes: Curimatidae), at Patos-Mirim lagoon system, Rio Grande do Sul state, Brazil. Panam J Aquat Sci 9(1): 43-47.

Corrêa, F., Oliveira, E.F., Pouey, J. \& Piedras, S. 2015. Length-weight relationships of 18 fish species from the Siluriformes order in a hydrographic subtropical basin in southern Brazil. J Appl Ichthyol 31: 1-3, http://dx.doi.org/10.1111/jai.12822

Daga, V.S., Gubiani, E.A., Cunico, A.M. \& Baumgartner, G. 2012. Effects of abiotic variables on the distribution of fish assemblages in streams with different anthropogenic activities in southern Brazil. Neotrop Ichthyol 10: 643-652, http://dx.doi.org/10.1590/ S1679-62252012000300018.

Durigan, G., Guerin, N. \& Costa, J.N.M.N. 2013. Ecological restoration of Xingu Basin headwaters: motivations, engagement, challenges and perspectives. Philos Trans R Soc Lond B Biol Sci 368(1619): 20120165, http://dx.doi.org/10.1098/rstb.2012.0165.

Einhardt, M.D.S., Corrêa, F., Cavalheiro, A.C.M., Piedras, S. \& Pouey, J. 2014. New area of occurrence to Acestrorhynchus pantaneiro (Menezes, 1992) (Characiformes, Acestrorhynchidae) in the Chasqueiro stream basin, Patos-Mirim system, Rio Grande do Sul, Brazil. Bol Soc Zool Urug 23(1): 36-42.

Garcia, A.M., Bemvenuti, M.A., Vieira, J.P., Marques, D.M.L.M., Burns, M.D.M., Moresco, A. \& Condini, M.V.L. 2006. Checklist comparison and dominance patterns of the fish fauna at Taim Wetland, South Brazil. Neotrop Ichthyol 4(2): 261-268, http://dx. doi.org/10.1590/s1679-62252006000200012.

Kotzian, H. \& Marques, D.M.L.M. 2004. Lagoa Mirim e a convenção Ramsar: um modelo para a ação transfronteiriça na conservação de recursos hídricos. Rev de Gest de Água da Amér Lat 1(2): 101-111.
Lévêque, C., Oberdorff, T., Paugy, D., Stiassny, M.L.J. \& Tedesco, P.A. 2008. Global diversity of fish (Pisces) in freshwater. Hydrobiol 595 (1): 545-567, http://dx.doi.org/10.1007/s10750-007-9034-0.

López-Fernández, H., Winemiller, K.O., Montaña, C. \& Honeycutt, R.L. 2012. Diet-morphology correlations in the radiation of South American geophagine cichlids (Perciformes: Cichlidae: Cichlinae). PLoS One 7(4): e33997, http://dx.doi.org/10.1371/journal.pone.0033997.

Lowe-McConnell, R.H. 1999. Estudos ecológicos em comunidades de peixes tropicais. São Paulo, EDUSP. 534p.

Lucena, C.A.S., Aldo, S.J. \& Vidal, E.S. 1994. Ocorrencia, distribuicao e abundancia da fauna de peixes da praia de Itapua, Viamao, Rio Grande do Sul. Comun Mus Ciênc Tecnol 7: 3-27.

Lucena, C.A.S., Castro, J.B. \& Bertaco, V.A. 2013. Three new species of Astyanax from drainages of southern Brazil (Characiformes: Characidae). Neotrop Ichthyol 11(3): 537-552, http://dx.doi.org/ 10.1590/S1679-62252013000300007.

Malabarba, L.R., Fialho, C.B., Anza, J.A., Santos, J.F. \& Silva, G.N.M. 2009. Biodiversidade dos campos do Planalto de Araucárias. 1ed. Brasília: MMA, v. 30: p. 131-156.

Malabarba, L.R., Neto, P.C., Bertaco, V.A., Carvalho, T.P., Santos, J.F. \& Artioli, L.G.S. 2013. Guia de Identificação dos Peixes da Bacia do Rio Tramandaí. Ed. Via Sapiens, Porto Alegre. 140p.

Matthews, W.J. 1998. Patterns in freshwater fish ecology. New York, Chapman \& Hall. 756p, http://dx.doi.org/10.1007/978-1-4615-4066-3.

Pendleton, R.M., Hoeinghaus, D.J., Gomes, L.C. \& Agostinho, A.A. 2014. Loss of rare fish species from tropical flood plain food webs affects community structure and ecosystem multifunctionality in a mesocosm experiment. PLoS ONE 9(1): e84568, http://dx.doi.org/ 10.1371/journal.pone.0084568.

Raghavan, R., Prasad, G., Anvar, A.P.H. \& Pereira, B. 2008. Fish fauna of Chalakudy River, part of Western Ghats biodiversity hotspot, Kerala, India: Patterns of distribution, threats and conservation needs. Biodivers Conserv 17(13): 3119-3131, http://dx.doi.org/10.1007/ s10531-007-9293-0.

Reis, R.E. \& Malabarba, L.R. 1988. Revision of the neotropical cichlid genus Gymnogeophagus Ribeiro, 1918, with descriptions of two new species (Pisces, Perciformes). Rev Bras Zool 4: 259-305, http://dx.doi.org/10.1590/S0101-81751987000400002.

Reis, R.E.; Kullander, S.O. \& Ferraris, JR C.J. 2003. Checklist of the freshwater fishes of South and Central America. Porto Alegre: EDIPUCRS. 742p.

Rodriguez, M.S. \& Reis, R.E. 2008. Taxonomic review of Rineloricaria (Loricariidae: Loricariinae) from the Laguna dos Patos drainage, southern Brazil, with the descriptions of two new species and the recognition of two species groups. Copeia 2: 333-349, http://dx.doi. org/10.1643/CI-06-218.

Santos, U., Silva, P.C., Barros, L.C. \& Dergam, J.A. 2015. Fish fauna of the Pandeiros River, a region of environmental protection for fish species in Minas Gerais state, Brazil. Check List 11(1): 1-7, http://dx.doi.org/10.15560/11.1.1507.

Silva, M.J., Ramos, T.P.A., Diniz, V.D., Ramos, R.T.C. \& Medeiros, E.S.F. 2014. Ichthyofauna of Seridó/Borborema: a semi-arid region of Brazil. Biot Neotrop v. 14: 1-6, http://dx.doi.org/10.1590/1676-06032014007713.

Schaefer, S.A. 1998. Conflict and resolution: Impact of new taxa on phylogenetic studies of the neotropical cascudinhos (Siluriformes: Loricariidae). pp. 375-400. In: Malabarba, L.M., Reis, R.E., Vari, R.P., Lucena, C.A.S., Lucena, Z.M.S. (eds.); Phylogeny and Classification of Neotropical Fishes, Edipucrs, Porto Alegre.

Schifino, L.C., Fialho, C.B. \& Verani, J.R. 2004. Fish Community Composition, Seasonality and Abundance in Fortaleza Lake, Cidreira. Braz Arch Biol and Techn 47(5): 755-763, http://dx.doi.org/10.1590/S151689132004000500011.

Schindler, D.E. 2007. Fish extinctions and ecosystem functioning in tropical ecosystems. Proc Natl Acad Sci 104: 5707-5708, http://dx. doi.org/10.1073/pnas.0700426104.

Sondotécnica, S.A. 1986. Distrito de Irrigação do Arroio Chasqueiro. Sumário. Estudo realizado para a SUDESUL-MI. 46p. 
Tagliani, P.R.A. 1994. Ecologia da assembléia de peixes de três riachos da Planície Costeira do Rio Grande Sul. Atlânt 16: 55-68.

Teixeira, T.P., Pinto, B.C.T., Terra, B.F., Estiliano, E.O., Gracia, D. \& Araujo, F.G. 2005. Diversidade das assembléias de peixes nas quatro unidades geográficas do rio Paraíba do Sul. Iheringia 95(4): 347-357.

Vaske T. Jr., Lessa, R.P., Nóbrega, M., Alegre-Quijano, S.M., Marcante, S.F. \& Bezerra, J.L.Jr. 2005. Checklist of fishes from Saint Peter and Saint Paul Archipelago, Brazil. J Appl Ichthyol 21: 75-79, http://dx.doi.org/10.1111/j.1439-0426.2004.00600.x.

Vannote, R.L., Minshall, G.W., Cummings, K.W., Sedell, J.R. \& Cushing, C.E. 1980. The River Continuum Concept. Can J Fish Aquat Sci 37: 130-137, http://dx.doi.org/10.1139/f80-017.

Villwock, J.A. 1987. Processos costeiros e formação de praias arenosas e campos de dunas ao longo da costa sul e sudeste brasileira.
Simpósio sobre ecossistemas da costa sul e sudeste brasileira: síntese dos conhecimentos. p. 380-399.

Vitule, J.R.S., Lima Junior, D.P, Pelicice, F.M, Orsi, L.M \& Agostinho, A.A. 2012. Ecology: Preserve Brazil's aquatic biodiversity (correspondence not peer-reviewed). Nature 485: 309-309, http://dx.doi.org/ $10.1038 / 485309 \mathrm{c}$.

Wiley, E.O. \& Johnson, G.D. 2010 A teleost classification based on monophyletic groups. In Nelson, JS., Schultze, H-P. and Wilson, M.V.H. (Eds.). Origin and Phylogenetic Interrelationships of Teleosts. München: Verlag Dr. Friedrich Pfeil. p. 123-182.

Winemiller, K O., Agostinho, A.A. \& Caramaschi, E.P. 2008. Fish Ecology in Tropical Streams. Pp. 107-146. In: Dudgeon, D. (Ed.). Tropical Stream Ecology. London, Elsevier, 343p., http://dx.doi. org/10.1016/B978-012088449-0.50007-8. 


\section{Erratum: Ichthyofauna of the hydrographic basin of Chasqueiro Stream (Mirim Lagoon system, southern Brazil): generating subsidies for conservation and management}

In the manuscript "Ichthyofauna of the hydrographic basin of the Chasqueiro Stream (Mirim Lagoon system, southern Brazil): generating subsidies for conservation and management" with DOI code number 10.1590/16760611-BN-2015-0006 published at Biota Neotropica 15(4): e0006

Where you read:

In 1977, a dam was constructed to prevent the entry of salt water into the region of Mirim Lagoon, the main water source used for agriculture, particularly for rice cultivation (Burns et al. 2006, Mouchet et al. 2012, Corrêa et al. 2015).

\section{Please read:}

In 1977, a dam was constructed to prevent the entry of salt water into the region of Mirim Lagoon, the main water source used for agriculture, particularly for rice cultivation (Burns et al. 2006, Corrêa et al. 2015). 